\title{
CM0 ENSAT Staging Finding v7
}

National Cancer Institute

\section{Source}

National Cancer Institute. CMO ENSAT Staging Finding v7. NCI Thesaurus. Code C104028.

Adrenal cancer with no involvement of distant organs or tissues. (7th Ed, 2009) 